\title{
The curdling of milk. A study of the curdling enzyme
}

\author{
BY \\ N. L. SÖHNGEN $\uparrow, K$. T. WIERINGA AND \\ A. PASVEER.
}

$\theta$

RECUEIL DES TRAVAUX CHIMIQUES DES PAYS-BAS, edited by the Nederlandsche Chemische Vereeniging ['s-Gravenhage, Holland].

Vol. 56, No. 2 (15 th February 1937).

D. B. CENTEN's Uitgevers-Maatschappij. Amsterdam. 
$637.16: 577.15$

\title{
THE CURDLING OF MILK. A STUDY OF THE CURDLING ENZYME
}

BY

\author{
N. L. SOHNGEN t, K. T. WIERINGA and A. PASVEER.
}

We have studied the action of the curdling enzyme on casein by making use of viscometric methods for determining the velocity of the action of the enzyme.

Under otherwise similar conditions, the velocity of action is determined by the ratio of casein to enzyme. The action is slower if the concentration of casein is increased or that of the enzyme reduced. The reaction is more rapid at lower concentrations of casein or higher concentrations of enzyme. It appears however, that at any given concentration of enzyme, the addition of more enzyme has no immediate effect on the velocity. This result makes it highly probable that the enzyme is adsorbed on the protein.

We have found that the velocity of the action of the enzyme is practically directly proportional to the hydrogen-ion concentration, which had been demonstrated previously by $\mathrm{v}$ a $\mathrm{Da} \mathrm{m}$ in an entirely different way. From various experiments we have reached the conclusion that the more rapid action of the curdling enzyme at higher hydrogen-ion concentrations is probably entirely and certainly for the greater part, due, not to a direct effect on the enzyme, but to an alteration in the state of the protein particle, by which the latter becomes more accessible to the enzyme.

The relationship between the swelling of the protein particle and the velocity of the action of the enzyme appears to be such that the action of the enzyme is slower the greater the swelling. The enzyme acts more rapidly when the particle is dehydrated.

We will again mention in this connection, that in no case can it be taken as a generalised statement that the action of the curdling enzyme (considered as the curdling process) is more rapid under conditions favouring less swelling. On the other hand there are investigations, which show, that with other enzymes (also even with the curdling enzyme as regards digestive action) the relationship between swelling and velocity of action is just the oppositie.

We also investigated the so called "specific action" of calcium-ions on the action of the enzyme. This was completely elucidated. The action of the enzyme takes place much more rapidly in a calcium caseinate sol than in a sodium caseinate sol having the same $p_{\text {II }}$ value. The explanation is now clear. In the calcium caseinate sol, which has a much lower viscosity than the sodium caseinate sol, the particles are much less swollen than in the latter sol. Thus the particles are much more accessible to the enzyme.

We have made no comments on this idea of the more or less greater accessibility of the protein particle depending on the degree of swelling. 
In two previous communications 1,2 ), it has been shown, among other things, that our knowledge of the effect of heating milk and of the curdling process is still very small. Various peculiar phenomena are not explicable in the present state of science and contradictory observations in the literature have not yet been elucidated. In particular, this state of affairs really arises from insufficient knowledge of the lab enzyme and of the calcium caseinate. It appeared that viscometric studies on both these topics would to a large extent make good the deficiency. It was mentioned, that insufficient attention has been paid to the investigation of $\mathrm{H} \mathrm{a} \mathrm{m} \mathrm{marsten}$. He showed more than half a century ago, that the curdling process consisted actually of two parts, viz. the actual enzyme process followed by coagulation. It was demonstrated that the coagulation process must be considered from a colloid chemical standpoint, while the enzyme process could be followed viscometrically, independently of the coagulation process, which was impossible in previous investigations.

It was immediately obvious therefore, that a study of the lab enzyme should be taken in hand anew. This communication is to be considered as a first step in this direction.

The effects of the following factors on the clotting enzyme have been studied:

1. the casein concentration; 2 . the enzyme concentration and 3 . the hydrogen-ion concentration.

At the same time we had to concern ourselves with the question as to how far calcium-ions effected the action of the enzyme as well as the coagulation process 2 ).

Reference may be made to a previous communication ${ }^{2}$ ) for the preparation of the casein. Sols were prepared by grinding a known weight of casein in a mortar with dilute sodium hydroxide solution. The smooth paste, which one obtains by careful working, was poured out into a flask and the casein peptised by warming the flask for some hours in a water bath at $40^{\circ}$, peptisation being facilitated by repeated shaking. The sol was then cooled for at least 16 hours in the ice chest. Before use the solution was filtered through de-fatted cotton wool in order to remove small particles of undissolved casein, which might block the capillary of the viscometer. The $p_{H}$ of the sol, which can be regulated by the amount of alkali, which is added, was always checked.

The dialysis of the rennet, which is absolutely necessary ${ }^{2}$ ) was carried out against running tap water in small collodion bags. The

1) A. Pasve e r, Landbouwkundig Tijdschrift, 46, 630 (1934).

2) A. Pasveer and H. J. C. Tendel oo, ibid, 46, 814 (1934). 
small amount of calcium salt, which remained behind in the rennet after this treatment, had no apparent effect on our casein sols so that dialysis against distilled water was dispensed with. A few drops of toluene were added to the commercial rennet to be dialysed (about $20 \mathrm{~cm}^{3}$ the undissolved portion being removed after dialysis to freedom from chloride by filtration through wool. The small amount of dissolved toluene had no effect on the action of the enzyme ${ }^{3}$ ). Freshly dialysed rennet was used for each series of experiments. Wherever possible, each series of experiments was finished within 24 hours.

Following the action of the enzyme viscometrically. In the following formula, $P$ is a measure of the hydration of the casein particle in percentages of the initial condition ${ }^{2}$ ):

$$
P: 100=\frac{\eta(s+a . e) t^{-1}}{\eta(s+g . e)}
$$

$P$ was measured as follows:

One $\mathrm{cm}^{3}$ of dialysed rennet was added to $40 \mathrm{~cm}^{3}$ of a casein sol after it had been heated for half an hour at $65^{\circ}$ to kill the enzyme. The relative viscosity of this mixture measured at $30^{\circ}$ is the initial viscosity at which $P=100$. In another experiment, $1 \mathrm{~cm}^{3}$ of distilled water was added instead of the rennet and it was found that the viscosity was the same in both cases.

The effect of the active enzyme on the viscosity of the sol was now determined in mixtures of sol and a similar amount of active enzyme at $30^{\circ}$. The viscometer was immediately filled and after adjustment of the unavoidable small drop in temperature, (i.e. after about one minute), the first measurement was carried out. The succeeding measurement was commenced immediately after the first reading had been taken.

In all probability, the active rennet undergoes slow denaturation at $30^{\circ}$. In order therefore to prevent alterations in the strength of the enzyme it was kept at room temperature.

1. The effect of the casein concentration. When making sols of different concentrations, at greater dilutions there was a tendency towards thread formation which interfered with the measurements by stopping up the capillary of the viscometer. This phenomenon occurred to a lesser extent when the various sols were made separately at each concentration instead of being prepared by diluting a concentrated sol. Even then, at low concentrations threads were sometimes formed, which

3) Ch. Porcher, "Le lait au point de vue colloidal". 
had to be removed immediately before use by filtration. The very small alteration in concentration consequent upon this operation was neglected. The casein was peptised with $9.5 \mathrm{~cm}^{3}$ of $0.05 \mathrm{~N}$.sodium hydroxide per gram of casein. The $p_{\mathrm{H}}$ of the sols varied from 6.80 to 6.81 .

From Table $I$ and graph $I$, it appears that the fall in viscosity is more rapid the lower the concentration of casein, which is clear from the ratio enzyme concentration : casein concentration.

Table I.

$3 \%$ sol

initial viscosity 2.109

\begin{tabular}{|c|c|c|c|}
\hline $\begin{array}{l}\text { time after mixing } \\
\text { to the middle } \\
\text { of the viscosity } \\
\text { measurement }\end{array}$ & $\begin{array}{c}\text { time of outhow } \\
\text { of } \\
\text { viscometer }\end{array}$ & $\begin{array}{l}\text { relative } \\
\text { viscosity }\end{array}$ & $P$. \\
\hline $\begin{array}{l}6 \text { min } \\
9 \\
12 \\
15 \\
18 \\
21^{1 / 2} \\
25 \\
27^{4 / 3} \\
31 \\
34 \\
37 \\
39^{3 / 4} \\
42^{3 / 4} \\
45^{3 / 4} \\
48^{3 / 4} \\
51^{3 / 4} \\
54^{3 / 4} \\
57^{1 / 2} \\
60^{1 / 2} \\
63^{1 / 4} \\
66 \\
72\end{array}$ & $\begin{array}{l}2^{\prime} 13.3^{\prime \prime} \\
2^{\prime} 10.7^{\prime \prime} \\
2^{\prime} 6.0^{\prime \prime} \\
2^{\prime} 7.35^{\prime \prime} \\
2^{\prime} 5.95^{\prime \prime} \\
2^{\prime} 4.6^{\prime \prime} \\
2^{\prime} 3.55^{\prime \prime} \\
2^{\prime} 2.55^{\prime \prime} \\
2^{\prime} 1.75^{\prime \prime} \\
2^{\prime} 0.85^{\prime \prime} \\
2^{\prime} 0.6^{\prime \prime} \\
2^{\prime} 0.1^{\prime \prime} \\
1^{\prime} 59.8^{\prime \prime} \\
1^{\prime} 59.15^{\prime \prime} \\
1^{\prime} 58.4^{\prime \prime} \\
1^{\prime} 57.9^{\prime \prime} \\
1^{\prime} 57.6^{\prime \prime} \\
1^{\prime} 57.1^{\prime \prime} \\
1^{\prime} 56.9^{\prime \prime} \\
1^{\prime} 56.5^{\prime \prime} \\
1^{\prime} 56.5^{\prime \prime} \\
1^{\prime} 55.8^{\prime \prime}\end{array}$ & $\begin{array}{l}2.046 \\
2.006 \\
1.980 \\
1.955 \\
1.933 \\
1.913 \\
1.986 \\
1.881 \\
1.896 \\
1.855 \\
1.851 \\
1.842 \\
1.839 \\
1.829 \\
1.817 \\
1.810 \\
1.805 \\
1.797 \\
1.794 \\
1.788 \\
1.788 \\
1.777\end{array}$ & $\begin{array}{l}94.3 \\
90.7 \\
88.4 \\
86.1 \\
84.1 \\
82.3 \\
80.8 \\
79.4 \\
78.4 \\
77.1 \\
76.7 \\
75.9 \\
75.7 \\
74.7 \\
73.7 \\
73.0 \\
72.6 \\
71.9 \\
71.6 \\
71.1 \\
71.1 \\
70.1\end{array}$ \\
\hline $2 \%$ sol & initial viscos & & \\
\hline $\begin{array}{l}5 \text { min. } \\
73 / 4 \\
101 / 4 \\
12^{1 / 2} \\
15 \\
171 / 2 \\
19^{3 / 4} \\
22 \\
241 / 2 \\
26^{3} / 4 \\
29 \\
31^{1 / 2} \\
33^{3} / 4\end{array}$ & $\begin{array}{l}1^{\prime} 42.4^{\prime \prime} \\
1^{\prime} 41.2^{\prime \prime} \\
1^{\prime} 40.2^{\prime \prime} \\
1^{\prime} 39.4^{\prime \prime} \\
1^{\prime} 38.5^{\prime \prime} \\
1^{\prime} 38.25^{\prime \prime} \\
1^{\prime} 37.2^{\prime \prime} \\
1^{\prime} 36.55^{\prime \prime} \\
1^{\prime} 36.4^{\prime \prime} \\
1^{\prime} 35.95^{\prime \prime} \\
1^{\prime} 35.4^{\prime \prime} \\
1^{\prime} 35.4^{\prime \prime} \\
1^{\prime} 34.6^{\prime \prime}\end{array}$ & $\begin{array}{l}1.572 \\
1.553 \\
1.538 \\
1.526 \\
1.512 \\
1.508 \\
1.492 \\
1.482 \\
1.480 \\
1.473 \\
1.464 \\
1.464 \\
1.452\end{array}$ & $\begin{array}{l}93.9 \\
90.8 \\
88.3 \\
86.3 \\
84.1 \\
83.4 \\
80.8 \\
79.1 \\
78.8 \\
77.7 \\
76.2 \\
76.2 \\
74.2\end{array}$ \\
\hline
\end{tabular}


$1 \%$ sol initial viscosity 1.233

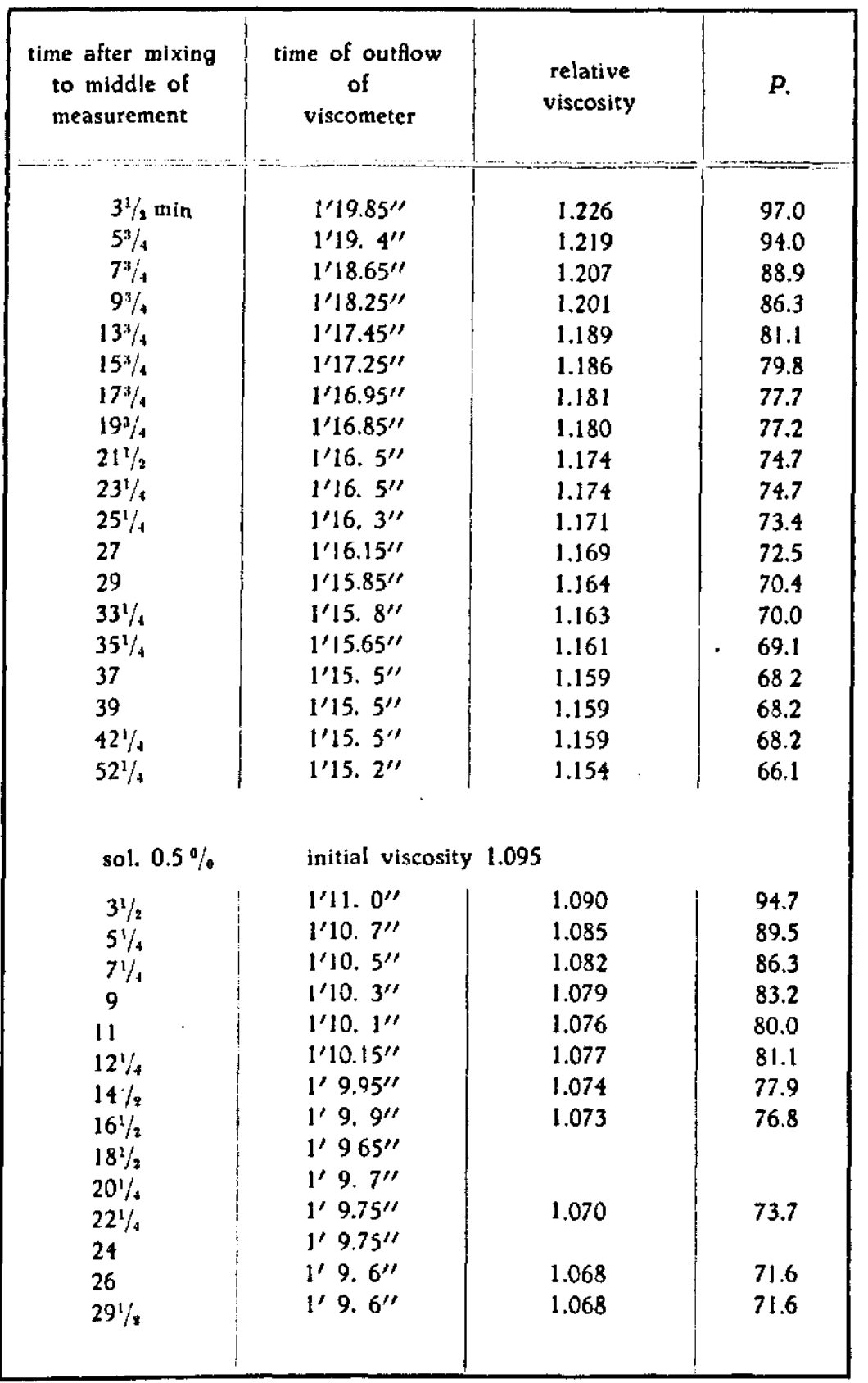




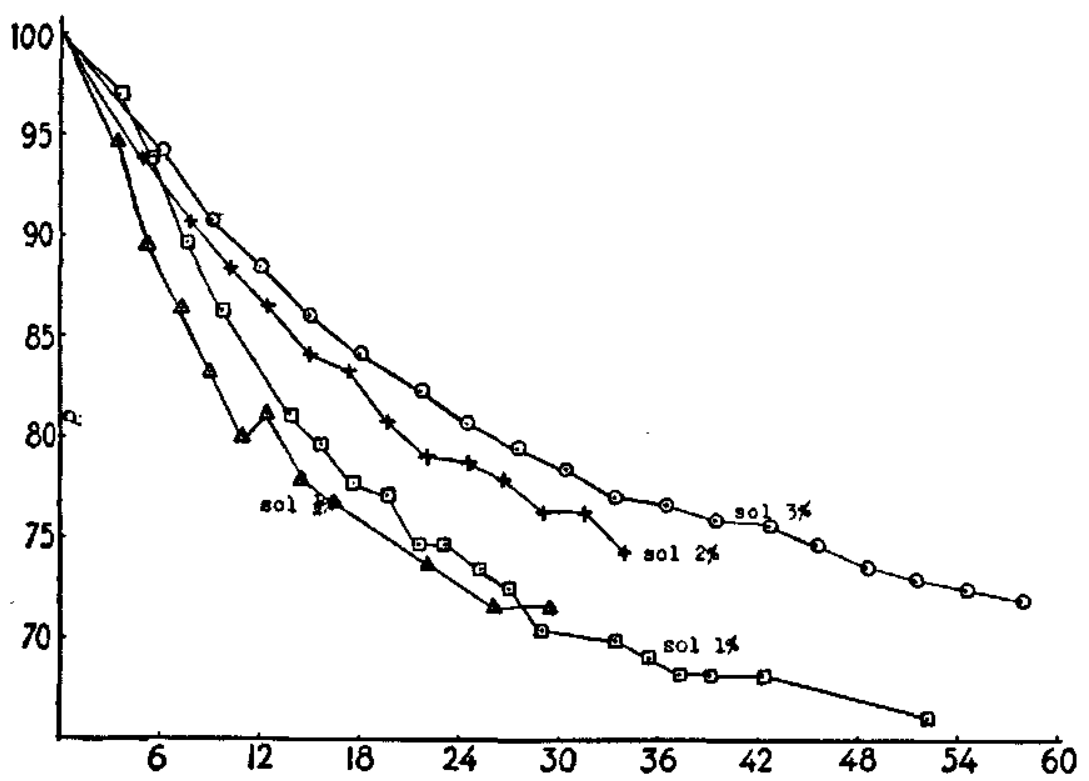

Time in minutes.

Figure 1. Changing casein-concentration. Equal enzyme-volume-concentration.

2. The effect of enzyme concentration. It is frequently assumed that in the curdling of a definite quantity of milk with various concentrations of enzyme, the product of the enzyme concentration and the curdling time remains constant. It has been usual even to speak of a time law. In our experiments with sols of sodium caseinate it has been found that increasing the enzyme concentration clearly influences the fall in viscosity. With increasing concentration of enzyme however, a limit is very soon reached above which increasing the concentration of enzyme has no further influence. Graph 2 clearly illustrates this phenomenon. The mixtures of caseinate sols and rennet were constituted as follows.

Table II.

\begin{tabular}{|c|c|c|c|}
\hline & $\begin{array}{c}\mathrm{cm}^{3} 2 \% \\
\text { sol. }\end{array}$ & $\mathrm{cm}^{3}$ water & $\begin{array}{c}\mathrm{cm}^{3} \text { active } \\
\text { enzyme }\end{array}$ \\
\hline \hline A & 40 & 5 & - \\
B & 40 & - & 5 \\
C & 40 & 1 & 4 \\
D & 40 & 2 & 3 \\
E & 40 & 3 & 2 \\
F & 40 & 4 & 1 \\
\hline
\end{tabular}


As previously, we found here also that as the ratio enzyme conc. : casein conc. increased the fall in viscosity became more rapid. This is true, however, only to a certain limit. When the ratio is large, the rule no longer holds. This is probably one of the causes of the

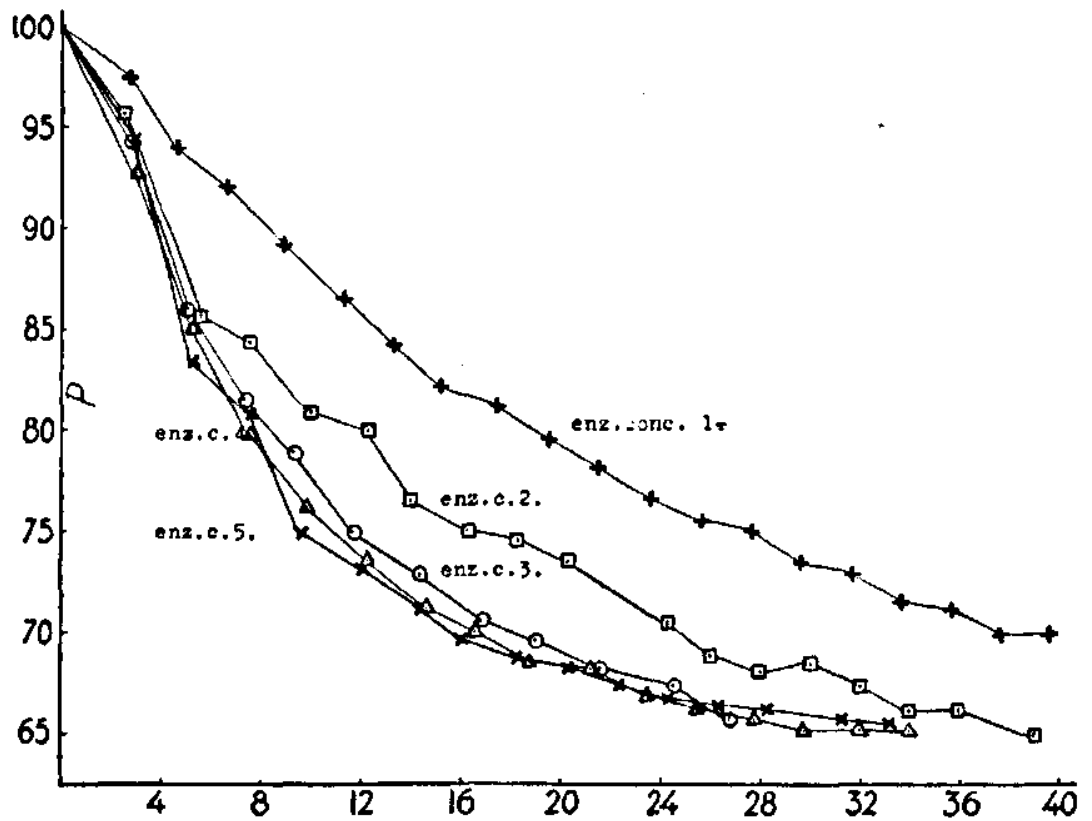

Time in minutes.

Fig. 2. Equal casein-concentration. Changing enzyme concentration.

discovery of deviations from the time law mentioned above. At higher concentrations of enzyme this law certainly does not hold. In our opinion the results obtained can be simply explained on the assumption that the enzyme is adsorbed on the casein. The more rapid action of the enzyme at lower concentrations of casein and the attainment of a maximum as the enzyme concentration increases are the natural consequence of this assumption.

In order to test this hypothesis more closely, the velocity of enzyme action has been measured on a number of casein sols all of which contained the same ratio of enzyme to casein, while the volume concentrations of both substances varied as follows.

The initial viscosities were measured in sols $A_{1}, B_{1}$ and $C_{1}$, while the action of the enzyme was measured in sols $A_{2}, B_{2}$ and $C_{2}$. It is clear from graph 3 that the attack on the protein takes place with the same velocity in all three cases. Thus under otherwise similar conditions. 
the velocity of the change is dependent on the ratio of enzyme to casein and at any particular ratio of enzyme to casein is independent of the dilution.

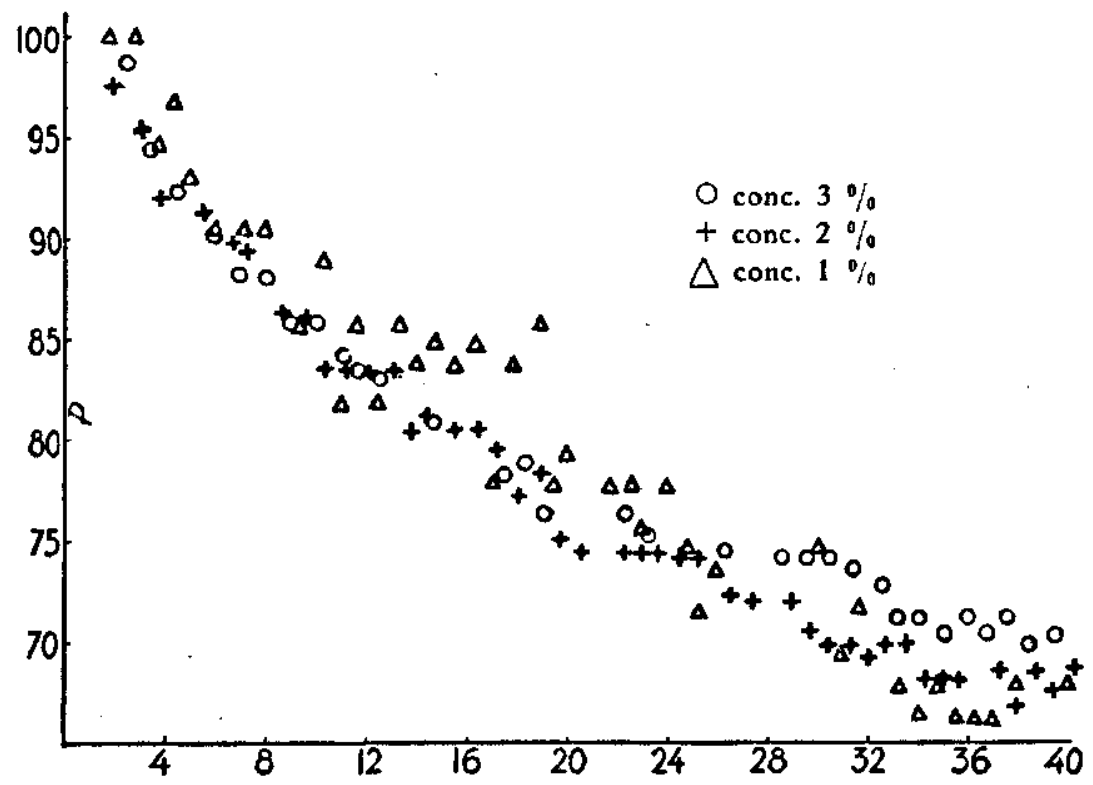

Time in minutes.

Fig. 3. Changing concentrations. Equal ratio enzyme/casein.

Table III.

\begin{tabular}{|c|c|c|c|}
\hline & $\mathrm{cm}^{3}$ & $\mathrm{~cm}^{3}$ water & $\begin{array}{c}\mathrm{cm}^{4} \text { active } \\
\text { enzyme }\end{array}$ \\
\hline $\mathrm{A}_{1}$ & $403 \%$ sol. & 5 & - \\
$\mathrm{A}_{2}$ & $403 \%$ sol. & 3.5 & 1.5 \\
$\mathrm{~B}_{1}$ & $402 \%$ sol. & 5 & -- \\
$\mathrm{B}_{2}$ & $402 \%$ sol. & 4 & 1 \\
$\mathrm{C}_{1}$ & $401 \%$ sol. & 5 & - \\
$\mathrm{C}_{2}$ & $401 \% \%$ sol. & 4.5 & 0.5 \\
\hline
\end{tabular}

This result is in complete agreement with expectations and forms a powerful argument for the hypothesis that we have to deal with an adsorption of the enzyme on the protein.

3. The effect of the hydrogen-ion concentration. The sols so far investigated had a $p_{\mathrm{H}}$ value of about 6.8 and a sol was now prepared, by peptising casein with $5 \mathrm{~cm}^{3}$ of $0.05 N$.sodium hydroxide per gram of casein, which had a $p_{\mathrm{H}}$ value of about 6.1. Unlike the sols with 
higher $p_{H}$ values, sols with lower $p_{\mathrm{H}}$ values are milky white. Using this standard sol, the following mixtures were made, possessing different $p_{\mathrm{H}}$ values according to how much alkali was added.

Table IV.

\begin{tabular}{|c|c|c|c|c|c|c|}
\hline & $\begin{array}{c}\mathrm{cm}^{3} 2 \% \\
\text { Na sol. }\end{array}$ & $\mathrm{cm}^{3}$ water & $\begin{array}{c}\mathrm{cm}^{3} 0.05 \mathrm{~N} \\
\mathrm{NaOH} \\
\text { per gram } \\
\text { casein }\end{array}$ & $\begin{array}{c}\mathrm{cm}^{3} \\
\text { active } \\
\text { enzyme }\end{array}$ & pH val. & $\begin{array}{c}\text { rel. } \\
\text { viscosity }\end{array}$ \\
\hline \hline $\mathrm{A}_{1}$ & 40 & 5 & - & - & 6.13 & 1.569 \\
$\mathrm{~A}_{2}$ & 40 & 4 & - & 1 & & \\
$\mathrm{~B}_{1}$ & 40 & 4 & 1 & - & 6.35 & 1.548 \\
$\mathrm{~B}_{2}$ & 40 & 3 & 1 & -1 & & \\
$\mathrm{C}_{1}$ & 40 & 3 & 2 & - & 6.52 & 1.553 \\
$\mathrm{C}_{2}$ & 40 & 2 & 2 & 1 & & \\
$\mathrm{D}_{1}$ & 40 & 2 & 3 & - & 6.78 & 1.553 \\
$\mathrm{D}_{2}$ & 40 & 1 & 3 & 1 & & \\
$\mathrm{E}_{1}$ & 40 & 1 & 4 & - & 7.0 & 1.554 \\
$\mathrm{E}_{2}$ & 40 & - & 4 & 1 & & \\
\hline
\end{tabular}

The rates of the decrease in viscosity measured in nos. $A_{2}, B_{2}, C_{2}$, $D_{2}$ and $E_{2}$ are set out graphically in figure 4 , from which it appears that the velocity of the enzyme action increases regularly with the hydrogen-ion concentration $\left(\mathrm{H}^{\circ}\right)$. In order to investigate whether there is a definite parallel here, we have determined the product of the hydrogen-ion concentration $\left(\mathrm{H}^{*}\right)$ and the time necessary to reach a particular degree of dehydration.

Table V.

\begin{tabular}{|c|c|c|}
\hline$\left(\mathrm{H}^{\circ}\right) \times 10^{7}$ & $\begin{array}{c}\text { time necessary } \\
\text { to reach } \\
\mathrm{P}=90\end{array}$ & product \\
\hline 7.42 & $1.4 \mathrm{~min}$ & 10.4 \\
4.47 & 2.3 & 10.3 \\
3.02 & 3.7 & 11.2 \\
1.66 & 5.5 & 9.2 \\
1.0 & 10.5 & 10.5 \\
\hline
\end{tabular}

In the above tables this calculation is made for a small degree of dehydration to $P=90$ and for a later stage in the dehydration, namely, $P=80$. At the beginning especially, the product is satisfactorily constant, which indicates that the action of the enzyme is 


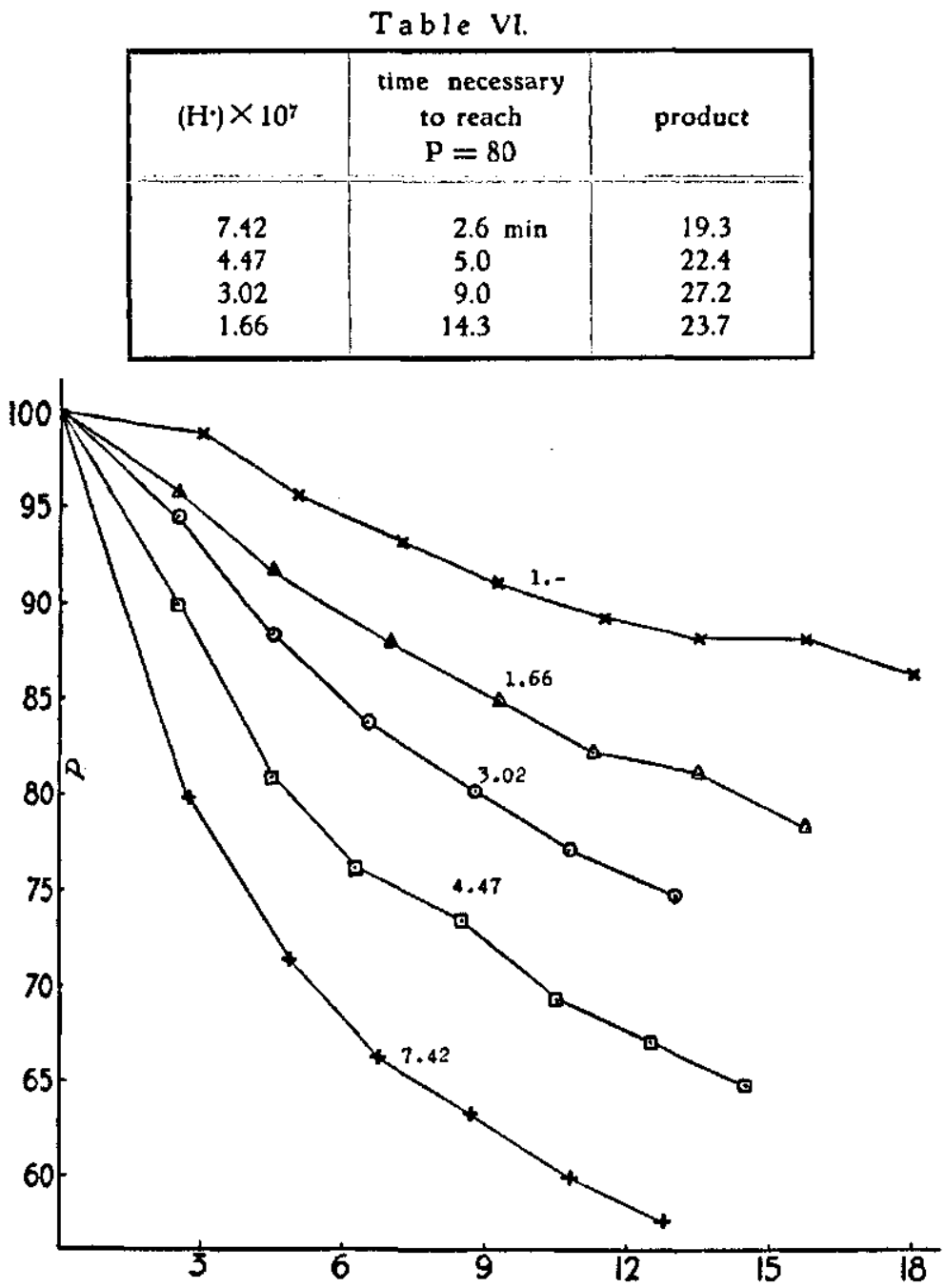

Time in minutes.

Fig. 4. Equal casein concentration. Equal enzyme concentration. Changing hydrogen-ion concentration.

Numbers refer to the hydrogen-ion concentrations $\times 10^{7}$.

directly proportional to the hydrogen-ion concentration. This confirms the results of $\mathrm{V}$ a n $\mathrm{Dam}{ }^{4}$ ), who reached the same conclusion in a totally different manner.

4) W. van Dam, Verslagen van landbouwkundige onderzoekingen der Rijkslandbouwproefstaions, No. V (1909). 
The parallelism no longer exists with higher states of dehydration. This appears quite clearly when the product of $t$ and $\left(\mathrm{H}^{*}\right)$ is determined at a dehydration of $P=75$.

Table VII.

\begin{tabular}{|c|c|c|}
\hline$(\mathrm{H}) \times 10^{7}$ & $\mathrm{t}$ of $\mathrm{P}=75$ & product \\
\hline 7.42 & $3.5 \mathrm{~min}$ & 26.7 \\
4.47 & 7.0 & 31.3 \\
3.02 & 13.0 & 39.3 \\
\hline
\end{tabular}

It appears that at lower $p_{\mathrm{H}}$ values the enzyme exerts a more powerful action in the long run. In any case there are deviations which agrees with the general experience, that in enzyme processes, certain regularities are only to be observed in the initial stages. Subsequently all sorts of factors influence the reaction.

If we consider the figures in table IV more closely, it is noteworthy that the relative viscosity remains the same in the region of $p_{\mathrm{B}} 6-7$, while in appearance the sodium sols of low $p_{\mathrm{H}}$ resemble the milky white calcium caseinate sols in the region of $p_{\mathrm{II}}$ of $6-7$, the viscosity of which is much lower in accordance with the lower degree of dehydration. The high viscosity is opposed to the apparent dehydrated condition of the milky white sodium caseinate sols $\left(p_{\mathrm{H}}=6\right)$. Let us suppose then that the sodium caseinate particle at a $p_{\mathrm{HI}}$ of 6 is surrounded by a fairly large mantle of water free from protein, while the caseinate particle itself contains very little water. On the other hand, at a $p_{\mathbf{B}}$ of 7 let us suppose that the caseinate particle is greatly swollen. The water no longer forms a protein free mantle round the particle but is taken up into the swollen particle.

This hypothesis would explain why:

1. the external appearance of the casein sols at $p_{\mathrm{H}}=6$ is the same as that of dehydrated sols. In this case there will be a big difference in the refractive index of the caseinate particle and the surrounding water. At $p_{\mathrm{Il}}=7$ this difference is much less.

2. the percentage volume of the particle remains unchanged and therefore why also the relative viscosity undergoes no change in the region $p_{\mathrm{H}} 6-7$.

The "free" water mantle round the particle at $p_{\text {If }}=6$ forms one complete whole with the particle as far as the internal friction is concerned. We will offer no opinion as to how this must be explained.

After the above mentioned experiments had given us some insight into the effects of various factors on the action of the clotting enzyme, 
we looked into the question whether calcium-ions had any influence on the enzyme process.

As has already been mentioned in the introduction, the curdling process must be considered as consisting of two parts, the action of the enzyme, followed by a coagulation process. In a previous communication ${ }^{2}$ ) only the coagulation was considered in so far as it was affected by calcium-ions and it appeared that the latter flocculated the partially dehydrated sol in the usual manner.

Frequently, some significance has been ascribed to the action of calcium-ions on the action of the enzyme. Some investigators go even so far (also in connection with other natural processes) as to ascribe to the calcium-ion as distinct from all other ions, a "specific action". The following experiments deal with this point.

4. The effect of calcium-ions on the enzyme process. We compared the effect of the enzyme on two casein sols of identical $p_{\mathrm{H}}$, one of which was prepared with sodium- and the other with calcium hydruxide. As described previously, the relative viscosities of these sols to which rennet had been added, were measured at definite intervals of time, while simultaneously, at each time period, $10 \mathrm{~cm}^{3}$ of the casein sol - rennet mixture were taken and heated rapidly to $100^{\circ}$ to make the rennet inactive. These samples were heated to $100^{\circ}$ for $15 \mathrm{~min}$, cooled rapidly to room temperatures and kept to determine the coagulability of the sol, the degree of dehydration of which was fairly accurately known. For this purpose sufficient calcjum chloride was added to each tube to bring the concentration to 0.016-normal. This is sufficient to coagulate the protein rapidly if it is sufficiently dehydrated (loc. cit. p. 281). The tubes were examined immediately after adding the calcium chloride.

Figure 5 shows the result of this experiment as far as the viscosity is concerned. It is seen that the decrease in the viscosity is actually accelerated to a marked degree by calcium-ions. The coagulation test showed that coagulation of the calcium caseinate sol was complete with only a slightly opalescent, supernatant liquor, even after $1.75 \mathrm{~min}$. In all subsequent tubes coagulation was practically instantaneous, while the supernatant liquid was practically clear. This was not the case, however, with the sodium caseinate sol. On the addition of calcium chloride, the sodium caseinate sol forms a milky white liquid, in which small, white flocks may be observed after the enzyme has been allowed to act for $4.75 \mathrm{~min}$. As the time of action of the enzyme is extended, these flocks become clearer and in the fifth tube (10.5 min.), begin to sink. The amount of precipitate increases in subsequent 
tubes but the liquid remains milky white even after the enzyme has acted for 20.5 minutes. An eleventh tube was clear after the enzyme

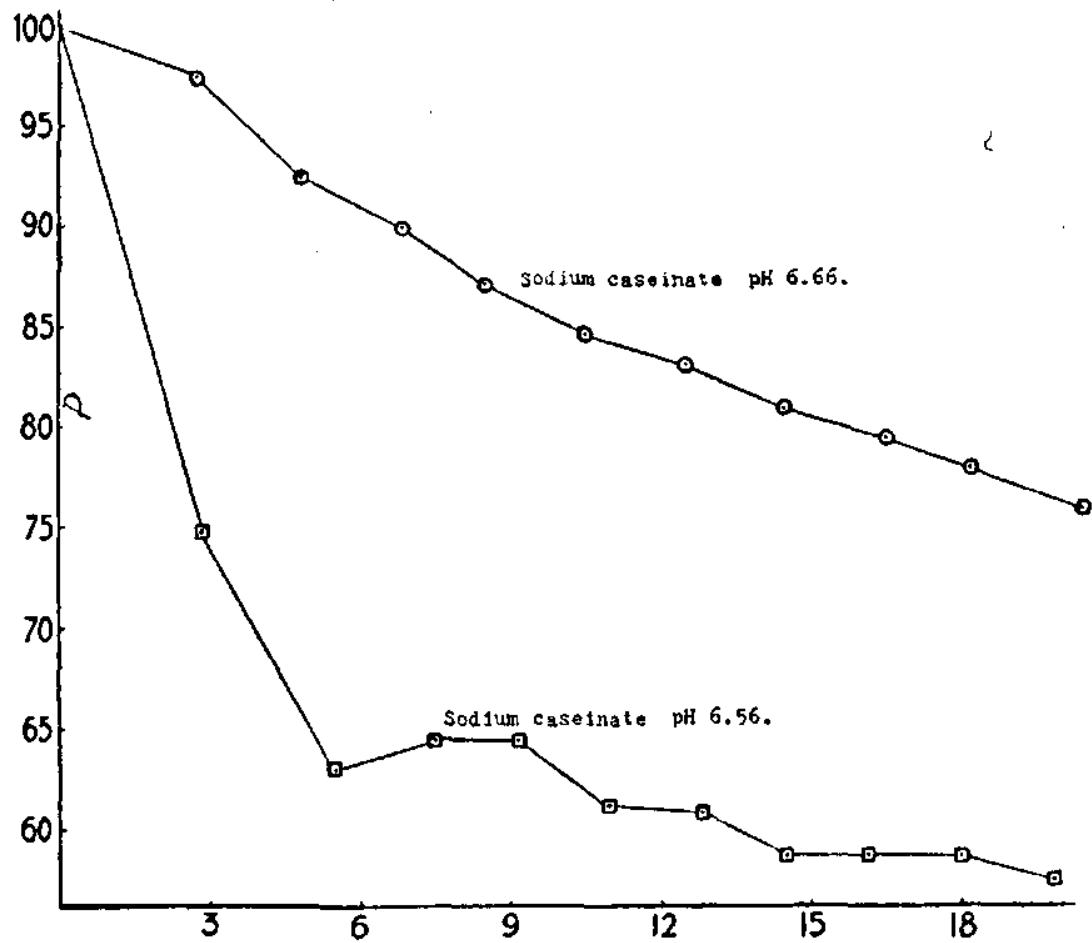

Time in minutes.

Fig. 5. "Specific action" of calcium ions.

had acted on the sodium caseinate sol for $80 \mathrm{~min}$. In this case the upper liquid was clear and a clotted coagulum was obtained.

It is obvious that the more rapid action of the enzyme on the calcium caseinate sol must be ascribed to the calcium-ions. It might be supposed that with the same velocity of enzyme action the viscosity of the calcium caseinate sol would decrease much more rapidly than that of the sodium caseinate sol on account of the much stronger dehydrating action of the calcium-ions. This cannot be the main cause of the observed difference, however, on account of the results obtained in the coagulation experiments. The sodium caseinate sol remained turbid with an excess of calcium chloride. Only when the sodium sol is sufficiently broken down, which was the case after 80 minutes action, can a coagulum with a clear supernatant liquid be obtained.

Thus it is definitely proved that the cloting enzyme acts more 
rapidly on the protein in the presence of calcium-ions. The question as to the reason for this more rapid action in the presence of calciumions goes a step further.

If we now consider the structure of the calcium caseinate particle and compare it with that of the sodium caseinate particle at $p_{\mathrm{H}} 6$ and 7 , we may assume, that at $p_{H} 7$, the calcium caseinate particle is relatively less swollen compared with the sodium caseinate particle at $p_{\mathrm{II}} 7$. Both particles have only a small water mantle. At $p_{\mathrm{II}} 6$, on the grounds of previously mentioned observations, we have considered the sodium caseinate particle in a slightly swollen condition but with a large water mantle. In accordance with these ideas we think of the calcium caseinate particle at $p_{\mathrm{BI}} 6$ as still less swollen, but furnished with a water mantle in agreement with the size of the calcium caseinate particle at $p_{\mathrm{H}} 7$.

For the subsequent investigation, we set out the hypothesis, that the velocity of enzyme action would be dependent on the swelling of the casein particle in this sense, that the action of the enzyme would be slower the more swollen the caseinate particle.

We have now modified the degree of dehydration of the casein particle in various ways. We have done this by adding different quantities of a particular electrolyte to a sodium caseinate sol, or by adding equivalent amounts of different electrolytes. Care was also taken that the $p_{\mathrm{HI}}$ of the sols in any particular series was the same or only very slightly different. At the same time, a study was made of the velocity of enzyme action on calcium caseinate sols at different $p_{\mathrm{II}}$ values, and finally of the breaking down of caseinate sols peptised with different bases. In all these experiments a smaller degree of swelling went parallel with a more rapid enzyme action. In these cases some ancilliary circumstances must be taken into account. Thus on adding calcium chloride to a sodium caseinate sol, the $p_{\mathrm{B}}$ falls. We tried to compensate this fall in $p_{\mathrm{H}}$ by adding alkali solution but were unable to obtain quite identical end values.

Table VIII.

\begin{tabular}{|c|c|c|c|c|}
\hline & $\begin{array}{l}\text { grams casein per } \\
100 \mathrm{~cm}^{3} \text { solution }\end{array}$ & conc. $\mathrm{CaCl}_{3}$ & $p_{\mathrm{H}}$ & $\begin{array}{c}\text { relative } \\
\text { viscosity }\end{array}$ \\
\hline $\mathrm{A}$ & 2 & - & 6.59 & 1.504 \\
$\mathrm{~B}$ & 2 & 0.008 & 6.70 & 1.412 \\
$\mathrm{C}$ & 2 & 0.016 & 7.00 & 1.304 \\
\hline
\end{tabular}

Making use of the rule (see p. 289) that the velocity of enzyme action is directly proportional to the hydrogen-ion concentration, the values 
found in these determinations have been re-calculated to a value at $p_{\mathrm{H}} 6.70$ (see fig. 6 full lines). Still another factor, which must be taken

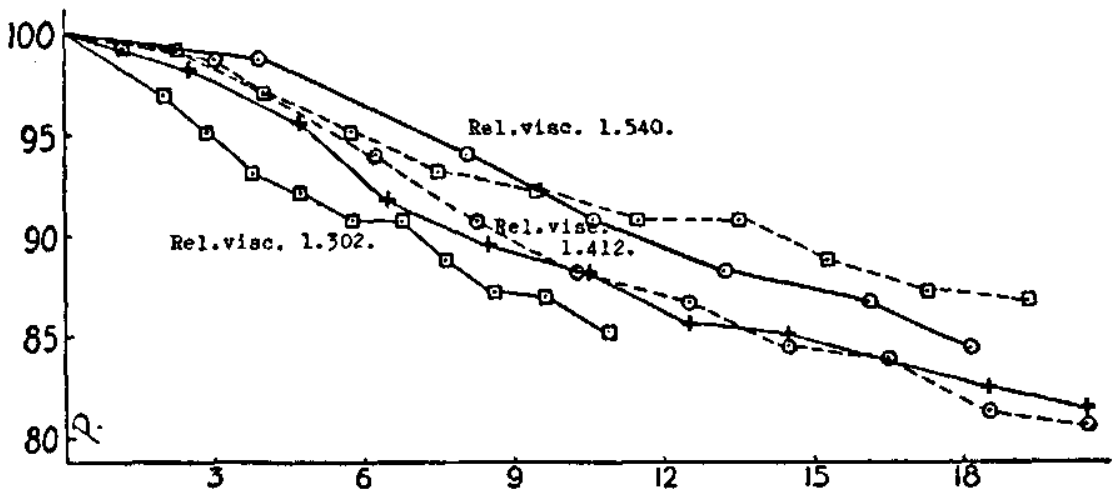

Time in minutes.

Fig. 6. Connection between the swelling of the casein particle and the velocity of the enzyme action.

The full lines give the values calculated to pn 6.70 .

into consideration, is the fact that the ions added may have a different effect on the viscosity of paracasein than on that of caseir. This phenomenon did actually show itself very plainly in an experiment

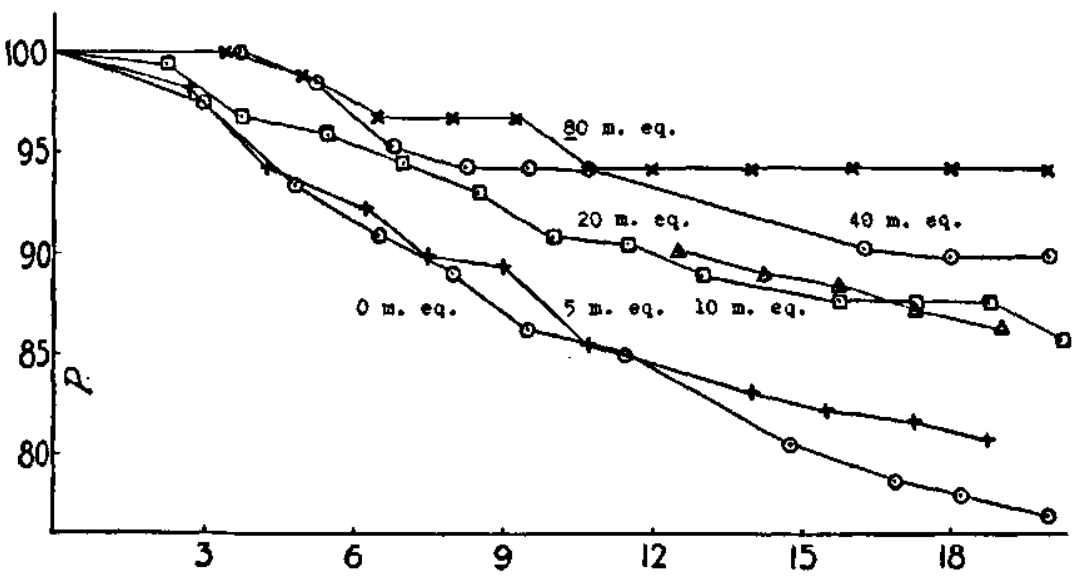

Time in minutes.

Fig. 7. The enzyme action in sols in which the particles are dehydrated by the addition of electrolytes.

The numbers give the final concentration of $\mathrm{NaNO}_{3}$.

in which different amounts of sodium nitrate were added to dehydrate the casein sol. The effect observed was of such a nature that the 
viscosity decreased much more slowly in sols with the highest sodium nitrate concentrations. This behaviour was exactly opposite to what was expected from the initial viscosity (table IX, fig. 7).

Table IX.

\begin{tabular}{|c|c|c|c|c|}
\hline & $\begin{array}{c}\text { conc. } \mathrm{NaNO}_{3} \text { in } \\
\text { millimol. }\end{array}$ & $\begin{array}{c}\text { relative } \\
\text { viscosity }\end{array}$ & $p_{\mathrm{u}}$ & $\begin{array}{c}\text { decreasing } \\
\text { viscosity }\end{array}$ \\
\hline $\mathrm{A}$ & - & 1.519 & 6.66 & quicker \\
$\mathrm{B}$ & 5 & 1.417 & 6.65 & \\
$\mathrm{C}$ & 10 & 1.354 & 6.63 & \\
$\mathrm{D}$ & 20 & 1.315 & 6.53 & \\
$\mathrm{E}$ & 40 & 1.278 & 6.34 & $\downarrow$ \\
$\mathrm{F}$ & 80 & 1.257 & 6.24 & slower \\
\hline
\end{tabular}

Our first impression was that the sodium nitrate poisoned the enzyme. This is untrue, however, for if calcium chloride is added to $F$ after the enzyme action has occurred, a coagulum is immediately produced, although the small decrease in the viscosity would indicate that only a very slight enzyme action had taken place.

If we combine the viscosity measurements with the determination of the coagulability, however, we see that lower initial viscosities go parallel with quicker coagulation, i. e. with more rapid enzyme action.

If the velocity of the enzyme action actually is determined by the condition of swelling of the casein particles, then in calcium caseinate sols of various $p_{\mathrm{II}}$ values, in which the differences in hydration are smaller than in the sodium caseinate sols, the difference in the velocity of enzyme action also must be smaller than in the sodium caseinate sols.

The composition and properties of such sols in which the effect of $p_{\mathrm{H}}$ is studied, are given in table $\mathrm{X}$.

Table X.

\begin{tabular}{|c|c|c|c|c|c|c|}
\hline & $\mathrm{cm}^{3}$ sol & $\mathrm{cm}^{3} \mathrm{H}_{2} \mathrm{O}$ & $\mathrm{cm}^{2}$ & $0.01 \mathrm{NCa}(\mathrm{OH})_{2}$ & $P_{\mathrm{H}}$ & rel. visc. \\
\hline $\mathrm{A}$ & 80 & 20 & 0 & 6.26 & 1.233 \\
$\mathrm{~B}$ & 80 & 16 & 4 & 6.37 & 1.233 \\
$\mathrm{C}$ & 80 & 12 & 8 & 6.56 & 1.217 \\
$\mathrm{D}$ & 80 & 8 & 12 & 6.69 & 1.201 \\
$\mathrm{E}$ & 80 & 4 & 16 & 6.90 & 1.201 \\
$\mathrm{~F}$ & 80 & 0 & 20 & 7.12 & 1.201 \\
\hline
\end{tabular}

The velocity of enzyme action is given in fig. 8. Lowering the value of $p_{\mathrm{II}}$ below about 6.5 has no further effect on the velocity of the enzyme action. On the other hand, lowering in this region has still an effect with sodium caseinate sols. In this case also, very slight 
alterations are observed in the relative viscosity at various $p_{\mathrm{G}}$ values, which is to be ascribed, in our opinion, to an increase in size in the water mantle at lower $p_{H}$ values.

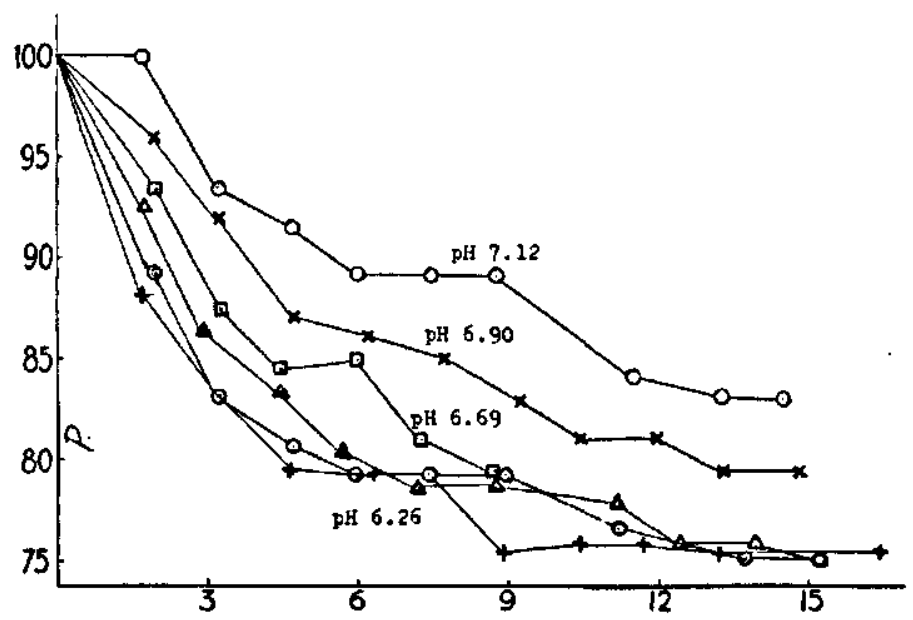

Time in minutes.

Fig. 8. The effect of changing hydrogen-ion concentrations on the velocity of enzyme action in calcium caseinate sols.

As with sodium caseinate sols, so also, although to a lesser degree with calcium caseinate sols, the enzyme acts more slowly at higher values of $p_{\mathrm{II}}$. Why should this be so? As far as our investigations take us at the moment, three factors may play a role.

1. Alteration in the swelling of the caseinate particle. The swelling of the protein particle is greater at higher $p_{\mathrm{H}}$ values. This follows among other things from the increased stability of the casein sol as $p_{\mathrm{H}}$ increases.

2. An effect of the hydrogen-ions on the action of the enzyme itself. Whether or not this effect is real, we cannot at the moment say. From the above experiments it must be assumed that the effect of the hydrogen-ions as such must be much smaller than was supposed.

3. Denaturation of the enzyme at higher $\mathrm{p}_{\mathrm{H}}$ values. The occurrence of this factor is very probable from the literature. It is quite certain, however, that this denaturation takes place less rapidly and only at higher $p_{\mathrm{H}}$ values than some investigators suppose. Even at $p_{\mathrm{H}} 7$ the hydration of the protein is more important. Depending on other circumstances, this may be so great that this hydration is sufficient to stabilise the paracasein and consequently no coagulation is obtained 
after the action of the enzyme. In this connection we will refer to a statement in a previous communication on the peptising action of sodium-ions present in large quantities in undialysed rennet (commercial rennet contains about $10 \%$ of sodium chloride).

In our previous experiments we have found in various directions support for the hypothesis that the velocity of enzyme action is dependent on the degree of swelling of the casein particle. Further support for this idea has been afforded by an experiment with casein sols peptised with different bases. Keeping $p_{\mathrm{H}}$ constant we should expect in this case to obtain difterent degrees of swelling in the sol, which would show up in the relative viscosities.

Table XI.

\begin{tabular}{|l|c|c|c|}
\hline Base & $\begin{array}{c}\mathrm{cm}^{3} 0.05 \mathrm{~N} \\
\text { per gram casein }\end{array}$ & $p_{\boldsymbol{h}}$ & $\begin{array}{c}\text { relative } \\
\text { viscoisty }\end{array}$ \\
\hline $\mathrm{NaOH}$ & 9 & 6.66 & 1.550 \\
$\mathrm{KOH}$ & 9.75 & 6.66 & 1.553 \\
$\mathrm{NH} \mathrm{OH}$ & 8.75 & 6.65 & 1.556 \\
$\mathrm{MgO}$ & $8(\mathrm{~m} . \mathrm{g})$ & 6.19 & 1.277 \\
$\mathrm{Ca}(\mathrm{OH})_{2}$ & $25($ lime water $)$ & 6.56 & 1.220 \\
$\mathrm{Ba}(\mathrm{OH})_{2}$ & 8.2 & 6.58 & 1.219 \\
\hline
\end{tabular}

According to their relative viscosities, these sols may be divided into two groups containing kations of the alkali group and the alkaline earth metals respectively. The former have a distinctly higher initial viscosity than the latter. In this connection we should expect the alkaline earth sols to show a much more rapid enzyme action, for which reason in these sols we use one part of enzyme to three parts of water. Thus in order to obtain comparative figures, the times required to reach a determined degree of dehydration must be multiplied by 0.25 . As we have already mentioned, this calculation is not exact, especially for higher concentrations of enzyme. In this case, however, it may be ignored on account of the very large differences which are observed and the fact that low enzyme concentrations were used (see fig. 9). It is quite obvious that at equal $p_{\mathrm{A}}$ values the velocity of the action of the enzyme varies considerably with the viscosity of the sol. The initial viscosities of the sodium, potassium and ammonium sols are practically identical; only a slight difference in the enzyme action occurs. The same holds for the calcium and barium sols, while the magnesium sols have an intermediate position. 


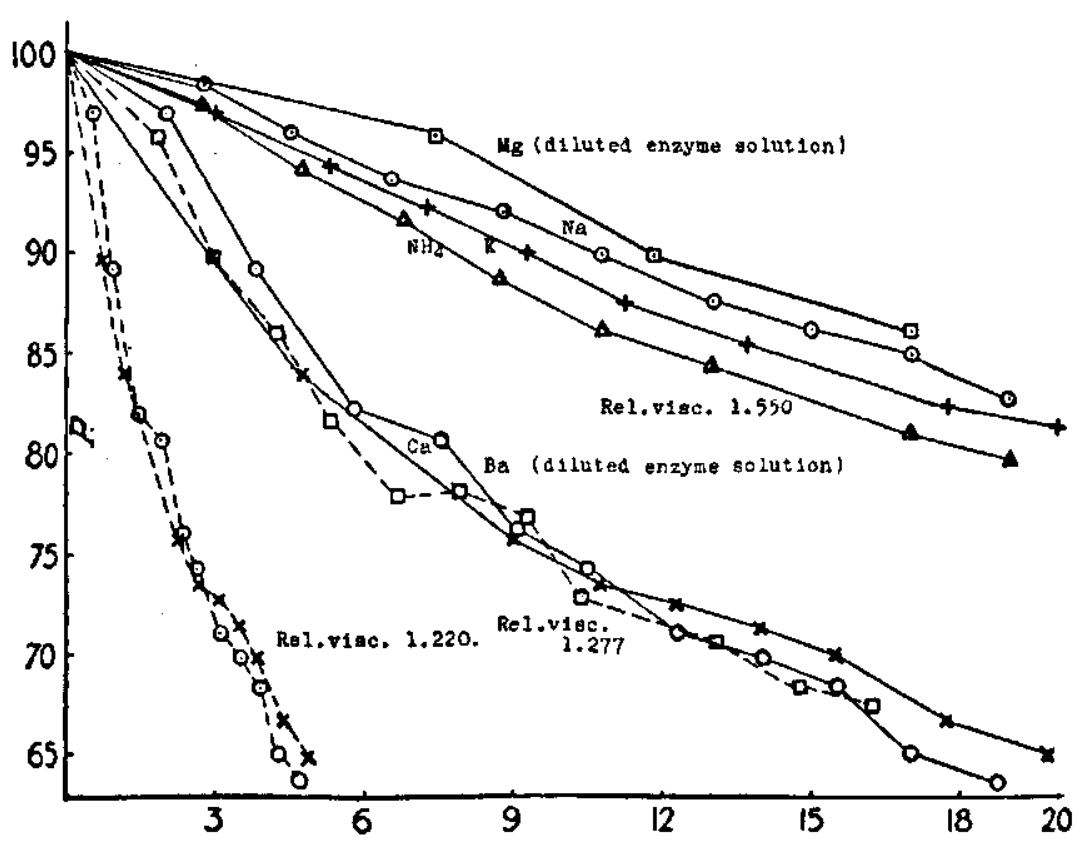

Time in minutes.

Fig. 9. The velocity of enzyme action in caseinate sols of various bases. []$\ldots \ldots, \square . \mathrm{Mg} . . \times \ldots, \times, \mathrm{Ca}_{1}, 0 \ldots \ldots, 0 . \mathrm{Ba}$ after correction.

General discussion.

In our experiments we have supposed that the dehydration is an accurate measure of the velocity of the enzyme action. This is not strictly correct.

In the first place, degradation of the casein molecule has a much greater effect on the dehydration in the early stages than when the enzyme has been acting for some time. Secondly, it is possible that the kations (anions?) present in the solution may have a different effect, during the action of the enzyme, on the degradation products than on the casein itself. That this is certainly the case as soon as salts are present in the solution, is clearly shown by the addition of sodium nitrate, which exerts a much less powerful dehydrating action on paracasein than on casein. It is impossible to say with certainty how far this occurs in solutions to which no salts have been added. We are inclined to assume, however, that if this is the case, it occurs only to a limited extent. With regard to the sodium-ions present, we consider that they are all pretty well orientated in positions, which they do not easily vacate. 
Thus although the velocity of dehydration is not to be considered as an absolutely accurate measure of the action of the enzyme, the following points hold:

1. That the dehydration is considered as the correct measure for elucidating the action of the enzyme as far as the curdling process is concerned. Hydration along with the charge is the determining factor for the coagulation.

2. If we take into due consideration the above mentioned two systematic errors, then following the enzyme process viscometrically can teach us a great deal with regard to the action of the enzyme itself, which is sufficiently self evident in the foregoing pages.

A very interesting question from many points of view is the connection between the velocity of the action of the enzyme and the configuration of the protein particle.

We may take it as proved that the effect of the hydrogen-ions on the course of the action of the enzyme is not to be sought in a direct effect on the latter, but is chiefly the result of alterations in the structure or configuration of the protein particle. This may be an important point for the study of other enzyme reactions especially as many enzymes really act on substrates, which are lyophyllic sols.

These investigations will be continued.

Finally we wish to express our sincere thanks to Dr. H. J. C. T endeloo, who has always afforded us help with the colloidchemical questions.

Wa geninge n, Microbiological Laboratory of the Agricultural University.

(Received 12th November 1936). 